\title{
Income Disparity as a Predictor of Happiness and Self-Esteem
}

\author{
Azmat Jahan $^{1 *}$, Namita Tyagi ${ }^{2}$, Sushma Suri ${ }^{3}$
}

\section{ABSTRACT}

Context: Researchers have studied extensively whether people with higher income are happier. But still there is a controversy among the researchers regarding the relationship between income and happiness. Few researchers have demonstrated a correlation between higher income and greater happiness (Clark, 2008 and Chicago Tribune, 2010). Whereas other found that happiness remained stagnant despite large increases in average real personal income. (Easterlin, 1974) 90 female high school teachers from private schools in Delhi and NCR were taken as a sample of the study. All the participants were equally divided into 3 groups on the basis of their income i.e. 15,000-20,000, 20,100 - 25,000 and 25,100 - 30,000 per month.

Context: Researchers have studied extensively whether people with higher income are happier. But still there is a controversy among the researchers regarding the relationship between income and happiness. Few researchers have demonstrated a correlation between higher income and greater happiness (Clark, 2008 and Chicago Tribune, 2010). Whereas other found that happiness remained stagnant despite large increases in average real personal income. (Easterlin, 1974) 90 female high school teachers from private schools in Delhi and NCR were taken as a sample of the study. All the participants were equally divided into 3 groups on the basis of their income i.e. 15,000-20,000, 20,100 - 25,000 and 25,100 - 30,000 per month.

Keywords: Income Disparity, Happiness, Self-Esteem and Business Policy.

An income disparity is most commonly an inequality in pay or salary for equal labor (Investor dictionary, 2014). This term is commonly used to describe the income differences between males and females for the same job or labour. However, they may be used in any situation when wages are arbitrarily different between two or more groups. Another term for the phrase economic disparity is economic inequality.

However, income disparity is also used by those people concerned with the low level of the minimum wage, relative to the income of the wealthy. In this context, it is not equal money for equal work as itis in the previous sense, but the sense that money should be a just reward, earned when deserved at the rate that is deserved. For example, many jobs the poor take on involve much harder labor than jobs the rich take, and some rich people never work. If that were the

\footnotetext{
${ }^{1}$ Ph.D. Scholar, Dept. of Psychology, Jamia Millia Islamia.

${ }^{2}$ Student, Dept. of Psychology, Jamia Millia Islamia.

${ }^{3}$ Assistant Professor, Dept. of Psychology, Jamia Millia Islamia.

*Corresponding Author

(C) 2015 I A Jahan, N Tvagi, S Suri; licensee IJIP. This is an Open Access Research distributed under the terms of the Creative Commons Attribution License (http://creativecommons.org/licenses/by/2.0), which permits unrestricted use, distribution, and reproduction in any Medium, provided the original work is properly cited.
} 
case, that would be income disparity, a man works all day and makes less money than a man that does not work.(Investor dictionary, 2014).Most of the studies have found that income is the major predictor of happiness and satisfaction. Individual whose basic needs are fulfilled with their income are regarded as happy and satisfied but even then, some studies have revealed that peoples' expectations have no ends, as Diener and Biswas-Diener (2002) argues that rising expectation create perpetual gap between material aspirations (things we would like to have) and current material possessions (things we already have), and a "chronic silence of desires". Rising expectations are one major reason more money does not bring more happiness. Our material expectations, wants, and desires always stay ahead of our incomes. Zee News,Tripathi, (2013) Inequality in earnings has doubled in India over the last two decades, making it the worst performer on this count of all emerging economies. The top $10 \%$ of wage earners now make 12 times more than the bottom $10 \%$, up from a ratio of six in the 1990s. So, the present study is incorporated to investigate whether income disparity or inequality affects individual's selfesteem and happiness.

\section{Self-Esteem:}

The most broad and frequently cited definition of self-esteem within psychology is Rosenberg's (1965), who described it as "totality of the individual's thoughts and feelings with reference to himself as an object." Self-esteem is generally considered the evaluative component of the selfconcept, a broader representation of the self that includes cognitive and behavioral aspects as well as evaluative or affective ones. Blascovich\&Tomaka, (1991) Self-esteem is how we value ourselves; it is how we perceive our value to the world and how valuable we think we are to others. Self-esteem affects our trust in others, our relationships, and our work - nearly every part of our lives. ASAP, (2014) Positive self-esteem gives us the strength and flexibility to take charge of our lives and grow from our mistakes without the fear of rejection. Following are some outward signs of positive self-esteem:

- Confidence

- Self-direction

- Non-blaming behavior

- Optimism

- An awareness of personal strengths

- An ability to make mistakes and learn from them

- An ability to accept mistakes from others

- An ability to solve problems

- The ability to say no

- An independent and cooperative attitude

- Feeling comfortable with a wide range of emotions

- An ability to trust others

- A good sense of personal limitations

- Good self-care 
What is low self-esteem? Low self-esteem is a debilitating condition that keeps individuals from realizing their full potential. A person with low self-esteem feels unworthy, incapable, and incompetent. In fact, because the person with low self-esteem feels so poorly about him or herself, these feelings may actually cause the person's continued low self-esteem.

Here are some signs of low self-esteem:

- Negative view of life

- Perfectionist attitude

- Blaming behavior

- Fear of being ridiculed

- Mistrusting others - even those who show signs of affection

- Fear of taking risks

- Feelings of being unloved and unlovable

- Dependence - letting others make decisions

Langner et al. (1970) investigated the relationship between income and self-esteem with a population of Manhattan school children. They found that self-confidence was at its lowest among low-income boys.

\section{Happiness:}

Defining happiness can seem as elusive as achieving it. The concept of happiness is the corner stone of the assumptions of positive psychology. Martin Seligman, one of the leading researchers in positive psychology and author of Authentic Happiness, describes happiness as having three parts: pleasure, engagement, and meaning. Keyes, Shmotkin, \&Ryff, (2002) there are two viewpoints or you can say two traditions of happiness. These are the hedonic and eudemonic approaches to happiness.

Hedonic well-being is based on the notion that increased pleasure and decreased pain leads to happiness. Hedonic concepts are based on the notion of subjective well-being. Subjective wellbeing is a scientific term that is commonly used to denote the 'happy or good life'. It comprises of an affective component (high positive affect and low negative affect) and a cognitive component (satisfaction with life). Carruthers \& Hood, (2004) It is proposed that an individual experiences happiness when positive affect and satisfaction with life are both high.

Eudaimonic well-being, on the other hand, is strongly reliant on Maslow's ideas of self actualisation and Roger's concept of the fully functioning person and their subjective well being. Keyes, (2002); Deci\& Ryan, (2000). Eudaimonic happiness is based on the premise that people feel happy if they experience life purpose, challenges and growth. This approach adopts SelfDetermination Theory to conceptualise happiness Seligman, Rashid and Parks, (2006) have proposed that happiness as a central focus of positive psychology can be broken down into three components: the pleasant life, the engaged life and the meaningful life. 
The pleasant life is the determinants of happiness as a desired state-what some people call the "good life". The engaged life is an aspect of happiness focused on active involvement in activities and relationship with others that express our talent and strengths and that give meaning to our lives. The meaningful life is an aspect of happiness that derives from going beyond our own self-Interests and preoccupations. The findings of Morawetz(1977) fit the intuition of many later scientists who believe that happiness depends on social comparison. In this view, people can derive unhappiness from comparing their level of wealth with the wealth of others, and in that line Clark (2003) claims that in Great Britain, comparing oneself with high income groups is linked to low life-satisfaction. On the basis of the above literature, following objectives were framed:

- To study income disparity as a predictor of happiness among high school teachers.

- To study income disparity as a predictor of self-esteem among high school teachers.

- To compare income disparity among three income groups on happiness.

- To compare income disparity among three income groups on self-esteem.

Based on above mentioned objectives, the hypotheses for the present research were as follows:

- Income disparity would be a significant predictor of happiness among high school teachers.

- Income disparity would be a significant predictor of self-esteem among high school teachers.

- There would be a significant difference among three income groups on happiness.

- There would be a significant difference among three income groups on self-esteem.

\section{METHOD}

The purpose of the present research is to study income disparity as a predictor of happiness and self esteem among high school teachers.

\section{SAMPLE:}

A total of 90 high school teachers were contacted for present study, they were further divided in three groups, (30 each) on the basis of income disparity, and three groups were divided on the basis of income ranging from 15000-20000, 20100-25000 and 25100-30000. Sample was collected from private schools of Delhi and ncr.

Income Of High School Teachers ( $\mathbf{N}=90)$

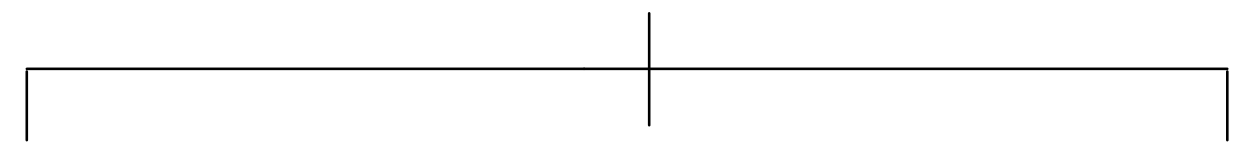
Rs 15000-20000
Rs 20100-25000
Rs 25100-30000
$(n=30)$
$(n=30)$
$(n=30)$ 


\section{TOOLS:}

Happiness: The happiness was measured by using Oxford happiness questionnaire (Michael Argyle and Peter Hills 1989). It has been derived from the Oxford Happiness Inventory, (OHI). The OHI comprises 29 items, each involving the selection of one of four options that are different for each item. OHQ demonstrated high scale reliabilities with values a (168) $=0.91$.

Self Esteem: The Self Esteem was measured using Rosenberg Self-Esteem Scale, a 10-item scale that measures global self-worth by measuring both positive and negative feelings about their self.

\section{PROCEDURE:}

For the purpose of present study 90 high school teachers were contacted from different private schools in Delhi\&ncr. The participants were informed that the information collected from them will be kept confidential and will be used only for the study of research purposes. The participants were asked to fill the questionnaires of happiness and self esteem.

Statistical Analysis: Regression analysis and one way anova has been used to analyse the data for present study.

\section{RESULT AND DISCUSSION:}

The present study was to assess disparity of income as predictors of happiness and self esteem in high school teacher (age 25-30) Obtained data were analysed by multiple regression and One Way ANOVA. Results are being presented in the following tables:

Table 1: Summary of regression analysis for the dependent variable of happiness of monthly income of high school teachers $(n=90)$.

\begin{tabular}{|l|l|l|l|l|}
\hline & $\mathbf{R}$ & R Square & Adjusted R Square & $\begin{array}{l}\text { Level of } \\
\text { significance }\end{array}$ \\
\hline income & $.754^{\mathrm{a}}$ & .568 & .564 & $.01^{*}$ \\
\hline
\end{tabular}

Predictor: (constant), Income Disparityl, Dependent Variable: Happiness

**Significant at .01 level.

Table 1 reveals the value of Multiple Correlation $(R=.754)$, the Multiple Correlation squared $\left(R^{2}\right.$ $=.568$ ), the adjusted Multiple Correlation squared (adj. $\left.R^{2}=.564\right)$, is found to be significant at .01 level, It means that we can say, with 99\% level of confidence, that 56.8 percent of the variation in average level of happiness can be predicted by disparity in a person's monthly income. Thus, Hypothesis I which says that "Income disparity would be a significant predictor of happiness among high school teachers" has been fully supported by the findings of the present investigation. Luttmer,(2004) states that Income inequality is unpleasant for those who earn less than others. 
Table 2: Summary of regression analysis for the dependent variable of self esteem of income disparity of high school teachers $(n=90)$.

\begin{tabular}{|l|l|l|l|l|}
\hline & $\mathbf{R}$ & R Square & Adjusted R Square & Level of significance \\
\hline Income & .738 & .545 & .540 & $.01 *$ \\
\hline
\end{tabular}

Predictor: (constant), Income Disparity, Dependent Variable: Self Esteem.

**Significant at .01 level.

It can be seen from the above table that the value of Multiple Correlation $(R=.738)$, the Multiple Correlation squared $\left(R^{2}=.545\right)$ and the adjusted Multiple Correlation squared (adj. $R^{2}=$ .540),indicates the findings which says that 54.5 percent of the variation in average level of self esteem can be predicted by disparity in a person's monthly income. The findings suggested that income disparity is a significant predictor of esteem. Thus, Hypothesis Ii which says that "Income disparity would be a significant predictor of self esteem among high school teachers" has been fully supported by the findings of the present investigation. Becchetti \& Castriota (2007) found similar results as their study states that change in income significantly affect the change in life satisfaction and self-esteem.

Table 3: Summary results of inter-correlation of income disparity, happiness and self esteem of high school teachers $(\mathrm{N}=90)$.

\begin{tabular}{|ll|l|l|l|}
\hline & self-esteem & Happiness & income \\
\hline self-esteem & & & & \\
& & & & \\
\hline Happiness & Pearson Correlation & & & $.754^{* *}$ \\
& & & \\
\hline
\end{tabular}

**. Correlation is significant at the 0.01 level (2-tailed).

The above table revealed significant positive correlation between income disparity and happiness $(\mathrm{r}=.754)$ income disparity and self esteem( $\mathrm{r}=.738)$ and self esteem and happiness $(\mathrm{r}=640)$ which indicates that higher the amount of monthly income higher the level of happiness and self esteem and vice versa. Baumeister (2003) found that self-esteem has a strong relation to happiness. High self-esteem leads to happier outcomes regardless of stress or other circumstances. 
Table 4: Summary results showing the F values and level of significance.

\begin{tabular}{|ll|c|c|}
\hline & & F & Level of Sig. \\
\hline happiness & Between Groups & 76.072 & $.01^{* *}$ \\
& Within Groups & & \\
& Total & & \\
\hline self-esteem & Between Groups & & \\
& Within Groups \\
& Total & & \\
& & & \\
\hline
\end{tabular}

**.Significant at the 0.01 level (2-tailed).

F value is found to be significant, as depicted from the above table. The F value indicates that the three income groups differ significantly on happiness and self-esteem. the findings shown in above table clearly is clearly supported by $\mathrm{HO} 3$ There would be a significant difference among three income groups on happiness and $\mathrm{HO}$ 4There would be a significant difference among three income groups on self-esteem.

\section{CONCLUSION:}

Thus, the findings of the present investigation, as shown in Tables reveal that income disparity stands as predictor of happiness and self esteem among high schools teachers. Moreover, these results also indicate that high income is likely to predict high level of happiness and self esteem and vice versa. Although the present investigation is limited in many ways, it can be helpful for future researchers and can be used as a foundation on which future researchers can base their work. Moreover, the findings of this investigation are very important in that they reveal the significant role played by monthly income in mental health and social harmony.

\section{REFERENCES:}

Academic and Staff Assistance Program.(2014). Self-esteem. Retrieved from: http://www.ucdmc.ucdavis.edu/hr/hrdepts/asap/Documents/Self_esteem.pdf $\quad$ (10 march, 2014)

Ball, R. and Chernova, K. (2004) Absolute income, relative income and happiness Paper presented to the international society of quality of life studies (ISQOLS) Philadelphia, USA

Baumeister, R. F., Campbell, J. D., Krueger, J. I., \&Vohs, K. D. (2003). Does high selfe steemcause better performance, interpersonal success, happiness, or healthier rife styles? Psychological Science in the Public Interest, 4, 1-44.

Becchetti, L. \&Castriota, S.(2007). Does money affect happiness and self-esteem? The poor borrowers' perspective in a natural experiment. RePEc-Research Paper in Economics.

Blascovich, J., \&Tomaka, J. (1991). Measures of self-esteem. In J. P. Robinson, P. R. Shaver, \& L. S. Wrightsman (Eds.) Measures of personality and social psychological attitudes, I. San Diego, CA: Academic Press. 
Carruthers, C, \& Hood, C. (2004). The power of the positive: Leisure and wellbeing.Therapeutic Recreation Journal, 38, 225-245.

Chicago Tribune.(2010). Price of joy? Survey says its \$75,000.September 5, 2010, 21.

Clark, A. (2003) Inequality aversion and social mobility: a direct test Delta Working Paper No. 2003-11, Paris, France.

Clark, Andrews, E., Frijters, P., \& Sheilds, M. A. (2008). Relative income, happiness and utility: An explanation for the Easterlin paradox and other puzzles. Journal of Economic Literature, 46, 95-144.

Deci, E.L., \& Ryan, R.M.(2000). The "what" and "why" of goal pursuits: Human needs self-determination of behaviour. Psychological Enquiry, 11, 227-268.

Diener, E, \&Biswas-Diener, R.(2002). Will money increase subjective well-being. A literature review and guide to needed research. Social Indicators Research, 57, 119-169.

Easterlin, Richard A., 1974 . "Does Economic Growth Improve the Human Lot?: Some Empirical Evidence,” in P. A. David and W. R. Levin eds., Nations and Household in Economic Growth, Stanford University Press, pp. 98-125.

Hills, P., \& Argyle, M. (2002). The Oxford Happiness Questionnaire: A compact scale for the measurement of psychological well-being. Personality and Individual Differences, 33(7), 1073-1082.

Investor Dictionary. (2014). Income disparity. Retrieved from: http://www.investordictionary.com/definition/income-disparity. (2 March, 2014)

Keyes, C. L. M., Shmotkin, D., \& Ryff, C. D. (2002).Optimizing well-being: The empirical ncounter of two traditions. Journal of Personality and Social Psychology, 82, 1007-1022.

Langner, Thomas, Edward Greene, Joseph Herson, Jean James on, Jeanne Goff, John Rostkowski and David Zykorie.1970. "Psychiatric impairment in welfare and no welfare children.”In Psychological Factors in Poverty, edited by Vernon Allen. Institute for Research on Poverty: Madison, Wisconsin.

Luttmer, E. (2004). Neighbors as negatives: relative earnings and well-being KSG Faculty Research Working Paper Series RWP04-029. Retrieved fromhttp://users.nber.org/ luttmer/relative.pdf(12 March 2014)

Morawetz, D. (1977) Income distribution and self-related happiness: some empirical evidence Economic Journal, 87(347), 511-522.

Seligman, M.E.P., Rashid, T., \& Parks, A.C. (2006) Positive Psychotherapy. American Psychologist, 61, 774-788.

Tripathi, S. (2013). Facts: economic disparity in India. Zee News. Retrieved from: http://zeenews.india.com/bbv/economic-disparity-in-india_878713.html (13 March, 2014)

Web

Investordictionary, http://www.investordictionary.com/definition/wages 